\title{
Attitudes toward Corporate Responsibilities in Western Europe and in Central And East Europe
}

\section{Olivier Furrer • Carolyn P. Egri • David A. Ralston • Wade Danis • Emmanuelle Reynaud • Irina Naoumova • Mario Molteni • Arunas Starkus • Fidel León Darder • Marina Dabic • Amandine Furrer- Perrinjaquet}

\section{Abstract and Key Results}

- This study investigated the attitudes toward social, economic, and environmental corporate responsibilities of 3064 current managers and business students in 8 European countries.

- Participants in Western European countries had significantly different perspectives on the importance of these corporate responsibilities (CR) than those in Central and East European countries. Within each country, environmental CR is perceived as most important in both CEE and Western European countries. Across countries, Western European respondents accord more importance to social CR and less importance to economic CR. CEE countries are not homogenous, e.g., CR attitudes in the Czech Republic are closer to that of Western Europeans, possibly triggered by the accession to EU.

- Work experience (managers vs. business students) influences social and environmental orientations more than the economic orientation for only some countries. Generational differences were found as well: Business students attribute more importance to environmental $\mathrm{CR}$ and less importance to social CR than managers.

Keywords: Corporate Social Responsibilities - Europe - CEE - Social Responsibility • Economic Responsibility • Environmental Responsibility • Institutions

\section{Authors}

Associate Professor Olivier Furrer, Institute for Management Research, Radboud University Nijmegen, Nijmegen, The Netherlands ( $\bowtie$ o.furrer@fm.ru.nl).

Professor Carolyn P. Egri, Faculty of Business Administration, Simon Fraser University, Burnaby, Canada.

Professor David A. Ralston, Price College of Business, University of Oklahoma, Norman, USA. 
Assistant Professor Wade M. Danis, Institute of International Business, Georgia State University, Atlanta, USA.

Professor Emmanuelle Reynaud, IAE Aix-en-Provence, Université Paul Cézanne Aix-Marseille III, Aix-en-Provence, France.

Assistant Professor Irina Naoumova, Barney School of Business, University of Hartford, West Hartford, USA.

Professor Mario Molteni, ALTIS, Università Cattolica del Sacro Cuore, Milan, Italy.

Doctor Arunas Starkus, Centre for International Business and Economic Research (CIBER), Vilnius, Lithuania.

Senior Lecturer Fidel León Darder, Facultat d'Economia, Universitat de València, València, Spain.

Professor Marina Dabic, Faculty of Economics and Business, University of Zagreb. Zagreb, Croatia.

Doctor Amandine Furrer-Perrinjaquet, Skim Analytical, Rotterdam, The Netherlands. 


\section{Introduction}

Despite pressures from the European Union to achieve European-wide uniformity in corporate social and environmental responsibility (CSER) standards by encouraging companies to voluntarily assume responsibilities beyond their legal obligations and by requiring national governments to enforce the use of internationally agreed standards, there remain significant differences across European countries in the implementation of CSER policies and practices (European Commission 2001, 2002, Habisch/Jonker/Wegner 2005). Whereas ethical concerns have played a dominant role in Anglo-Saxon countries, environmental issues rule the CSER agenda in Northern Europe, and CSER is perceived as a means to advance social issues in Southern Europe (Habisch et al. 2005, Lenssen/Vorobey 2005). In Central and East Europe, there is less tangible evidence that CSER has been high on the business agenda. The accession of ten Central and East Europe (CEE) countries to the EU in 2004 and two more in January 2007 has raised significant concerns regarding corporate responsibility priorities in these transitional economies (Vaughan-Whitehead 2003). Within the European region, institutional and economic system integration presents substantial pressures for cross-national convergence on a high standard of corporate citizenship (Albareda/Lozano/Ysa 2007, De Schutter 2008). Given the current diversity in socio-economic contexts as well as cultural and political heritages across Europe (Antal/Sobczak 2007), is cross-national convergence in corporate responsibility an unrealistic ideal?

Corporate responsibility (CR) relates to societal expectations regarding the social (discretionary, ethical, legal), economic, and environmental conduct of business organizations (Carroll 1979, Shrivastava 1996). The concept of corporate social responsibility and views on what constitutes responsible corporate conduct has evolved substantially since the 1950s (Carroll 1999). That corporate responsibility is a reflection of societal expectations directs us to consider the socially constructed nature of CR perspectives and practices (Basu/Palazzo 2008). The European region provides a fruitful site for investigating research questions concerning the antecedents and evolution of CR perspectives. Whereas Western European countries have played a leadership role in the formulation and adoption of CR practices, CEE countries are still regarded as laggards in this regard. One factor may be that CEE managers' perspectives on CR remain influenced by their historical socialist legacy (Ericson 1991, Kornai 1992) that is incompatible with current Western European expectations of corporate citizenship. Another 
factor may be that the institutional uncertainty created by economic liberalization processes (Filatotchev/Buck/Zhukov 2000) is not conducive to the development of a managerial ideology that embraces corporate citizenship.

We posit that the realization of CR objectives is dependent on the CR perspectives of business managers who are instrumental in the implementation of corporate responsibility practices in organizations. However, a recent review of the extant literature (Egri/Ralston 2008) showed a lack of cross-national empirical research that directly compares CEE and Western European managers' attitudes towards all three CR dimensions. Hence, the following research questions have yet to be answered: To what extent are managerial perspectives on corporate responsibility priorities in CEE transitional economies different from those in Western European established economies? To what extent is the socialist legacy of communist countries reflected in managerial perspectives on the importance of various types of corporate responsibilities?

Given current disparities in CR performance, what are the prospects for CR convergence, or possibly crossvergence throughout Europe in the long term (Ralston 2008)? U.S.-based studies have identified a 'generation gap' in attitudes towards corporate responsibilities such that business students (future managers) have a more ethical orientation than current managers (e.g., Ibrahim/Angelidis/Howard 2006). In this multi-level, multi-country study, one of our goals is to identify whether such a generation gap in CR attitudes exists in European countries and if so, whether there is cross-national variation in the nature of these generational differences in CR attitudes. Of particular interest is ascertaining whether business students have more similar CR attitudes than current managers across CEE and/or Western European countries. A finding of greater attitudinal convergence among business students would imply that current differences in CR performance between Western European and CEE countries may diminish over time as the current generation of managers retire and is replaced by a new generation of managers. Hence, another research question we seek to answer in this study is: Are there generational differences in perspectives on corporate responsibilities in European countries?

To answer these research questions, we conducted a multi-level study of the CR attitudes of 3064 managers and business students in eight European countries. Four countries are in Western Europe (France, Italy, Spain, Switzerland), and four countries are in Central and East Europe (Croatia, Czech Republic, Lithuania, Russia). The perspectives of both managers and business students are particularly important for understanding the potential for high standards of corporate 
citizenship given their current and future decision-making roles in determining corporate strategy and practices (Agle/Mitchell/Sonnenfeld 1999, Hood 2003). As such, investigating the importance that managers and business students attribute to different corporate responsibilities (social, economic, and environmental) helps to understand the normative underpinnings of how companies might be expected to behave in different national contexts, today and in the future.

\section{Theoretical Background and Hypotheses}

Carroll (1979) identified four types of corporate social responsibilities: economic, legal, ethical, and discretionary (or philanthropic). Economic responsibilities are concerned with business's financial performance and the provision of goods and services. Legal responsibilities are concerned with compliance with societal laws and regulations. Ethical responsibilities relate to following societal moral codes of conduct, and discretionary responsibilities relate to voluntary involvement and support of wider societal entities. These responsibilities have been subsequently regrouped into two broad social (discretionary, ethical, and legal) and economic dimensions (Aupperle/Carroll/Hatfield 1985). While Carroll (1979) also identified the environment as a social issue that concerned businesses, the stakeholder view of organizations (Freeman 1984, Mitchell/Agle/Wood 1997) identifies environmental corporate responsibility as a third dimension pertaining to the responsibilities of organizations to have ecologically sustainable relationships with both biophysical and societal environments (Shrivastava 1996). In the following sections, we develop hypotheses regarding CR attitudes in CEE and Western European countries based on theories regarding the influence of societal institutions and economic wealth as well as generation cohort differences. Figure 1 presents the research model for this study.

[Insert Figure 1 about here]

\section{Influence of Societal Institutions and Economic Wealth on CR Attitudes}

Cross-national differences in CR priorities may be attributed to the influence of societal institutions such as legal and political systems (e.g., Aguilera/Rupp/Williams/Ganapathi 2007, Campbell 2007, Pinkston/Carroll 1994, Schlegelmilch/Robertson 1995). Institutions serve as constraints to regulate economic activities by providing the rules of the game (North 1990, p. 3). They interact with both individuals and organizations, and influence individuals' decisionmaking by signaling which norms, behaviors, and choices are acceptable and which are 
unacceptable (North 1990, Scott 1995). By providing limits to the set of behaviors and choices of individuals and organizations, institutions provide a stable structure for economic exchanges, thereby reducing uncertainty (North 1990). A country's institutional framework is comprised of formal and informal constraints on individual and organizational behavior (North 1990). Formal constraints include political, judicial, and economic rules and contracts, whereas informal constraints include the codes of conduct, norms of behavior, and conventions that are embedded in a country culture and ideology.

Economic wealth is another influential factor on $\mathrm{CR}$ attitudes and priorities. Economic wealth results in greater material prosperity (e.g., higher per capita income, productivity growth, technological advancement) and enhanced human capital (e.g., education and knowledge, population health) (Georgas/van de Vijver/ Berry 2004). Hence, individuals in wealthier countries have greater economic and human capital to address social and environmental concerns, as confirmed by the positive relationships between economic development level and the perceived importance of social responsibilities (e.g., Campbell 2007, Getz/Volkema 2001, Singhapakdi/Karande/Rao/Vitell 2001), and environmental concern (e.g., Diekmann/Franzen 1999, Kemmelmeier/Krol/Kim 2002). Economic wealth is also associated with more effective economic, political, and regulatory institutions to control corruption and ensure ethical business conduct (Glaeser/LaPorta/Lopez-de-Silanes/Shleifer 2004). This is consistent with slack resources theory which argues that firms with slack resources may have greater freedom to invest in corporate social and environmental responsibilities than firms that are in financial trouble (e.g., Waddock/Graves 1997). Therefore, to develop a foundation for our CR hypotheses, the individual values theories of those proffered by Klages (2005) or Schwartz (1992) could be used. However, given the macro-level influences upon CR that have been discussed in that literature base (e.g., legal systems, political systems, and economic wealth), we chose to lay the foundation of our hypotheses more from the sociological perspective, as Inglehart/Welzel (2005) and other have proposed.

\section{Attitudes towards Corporate Responsibilities in CEE and Western European Countries}

In respect to $\mathrm{CR}$ attitudes within Europe, we note that CEE countries' institutional frameworks differ from the institutional frameworks of Western European countries on two important and interrelated dimensions: the socialist legacy (Ericson 1991, Kornai 1992), and economic 
development level and growth rate (Filatotchev et al. 2000). CEE countries are transitional economies with a rapid pace of economic development as well as rapid institutional changes as they move from planned economies to economic liberalization and the adoption of free-market systems (Hoskisson/Eden/Lau/Wright 2000). Compared to Western European economies, CEE countries are characterized by fundamental and comprehensive changes in the formal and informal rules of the game which affect firms and managers (Peng 2003). Furthermore, their rapid economic development is associated with systematic changes in legal, political, and cultural institutions (e.g., Inglehart/Welzel 2005, Kaufmann/Kraay 2002).

The economic liberalization in Central and East Europe and dismantling of central planning mechanisms have been accompanied by a sharp decline in production output and investment in major industrial sectors resulting in a prolonged structural crisis (Filatotchev et al. 2000). Inglehart and Welzel (2005) posit that industrial economies such as CEE transitional economies have a modernist values system that emphasizes individual achievement, materialism, deference to rational-legal authority, and maximization of economic growth goals. In advanced industrialized economies such as in Western Europe, high levels of economic security, technological development, and education engender the adoption of postmaterialist values that emphasize subjective well-being, self-expression, quality of life, as well as concern for the environment and others. Hence, individuals in CEE countries are likely to be more concerned with their personal economic situation and may be less willing to sacrifice their newly acquired wealth for the environment (Kemmelmeier et al. 2002). In richer and more stable countries such as those in Western Europe, individuals are more likely to have adapted to their current material level with the result being that other considerations, such as social welfare and environmental sustainability, may be relatively more salient (Inglehart/Welzel 2005).

In sum, these institutional and economic differences between CEE and Western European countries are likely to result in contrasting perspectives on the relative importance of social, economic, and environmental corporate responsibilities. Specifically, social and ethical corporate responsibilities are likely to be accorded higher importance in Western European countries given their more developed legal and political institutions aimed at eliciting responsible corporate conduct as well as high levels of economic and human capital to dedicate to CR activities (e.g., Aguilera/Cuervo-Cazurra 2004, Campbell 2007, Waddock/Graves 1997). In contrast, the less developed and more turbulent business regulatory and legal systems in CEE countries suggest 
that organizational financial considerations take higher precedence over social and environmental responsibility activities (Filatotchev et al. 2000, Vynoslavska/McKinney/Moore/Longenecker 2005).

Hypothesis 1a. Managers and business students in Western European countries attribute higher importance to social CR than those in CEE countries.

Hypothesis $1 b$. Managers and business students in CEE countries attribute higher importance to economic CR than those in Western European countries.

Hypothesis 1c. Managers and business students in Western European countries attribute higher importance to environmental CR than those in CEE countries.

\section{Generational Differences in CR Attitudes}

Moral development theory (Kohlberg 1981) suggests that individuals become more ethical with age and experience. However, empirical research on the relationship between age and sensitivity to unethical business practices has yielded mixed results with some studies finding a positive relationship (e.g., Weeks/Moore/McKinney/Longenecker 1999) and other studies not finding a significant relationship (e.g., Mitchell/Lewis/Reinsch 1992, Singhapakdi et al. 2001). Comparative studies of business managers/professionals and business students have also yielded mixed results. Consistent with moral development theory predictions, some studies have found business managers/professionals to be more sensitive to unethical practices than business students (Sparks/Hunt 1998, Wood/Longenecker/McKinney/Moore 1988). However, other studies have found the obverse with business students having higher ethical sensitivity (e.g., Ibrahim/Angelidis 1993, Smith/Skalnik/Skalnik 1999) and attributing higher importance to corporate ethical and discretionary responsibilities (Ibrahim et al. 2006) than business managers/professionals.

As proposed by Ibrahim et al. (2006), the current generation of business students may have more ethical predispositions as a result of recent corporate scandals about unethical business practices. Even so, the extent to which these U.S.-based results are generalizable to the European context remains to be established. Because the role of managers has been traditionally defined in economic terms, it is likely that managers will place a high priority on corporate economic issues (Sharfman/Pinkston/Sigerstad 2000). Further, current managers' greater maturity and experience may provide them with a greater appreciation of the "business world's economic realities" 
(Ibrahim/Angelidis 1993; Ibrahim et al. 2006). In contrast, empirical studies have consistently found that younger respondents have higher levels of environmental concern than older respondents (Diamantopoulos/Schlegelmilch/Sinkovics/Bohlen 2003). One explanation is that youth is associated with higher levels of postmaterialistic values (Inglehart/Welzel 2005). Hence, we propose the following:

Hypothesis 2a. Managers attribute higher importance to social CR than business students. Hypothesis $2 b$. Managers attribute higher importance to economic CR than business students. Hypothesis 2c. Business students attribute higher importance to environmental CR than managers.

The magnitude and nature of generational differences in CR attitudes may also be influenced by economic and institutional changes. CEE transitional economies have experienced rapid and significant changes in economic development, societal institutions, and political governance (Hoskisson et al. 2000, Peng 2003). Since there is general agreement that individuals develop their personal values system by adolescence (e.g., Inglehart/Welzel 2005), it may be the next generation of CEE managers whose attitudes toward CR have been most affected by recent developments supporting corporate citizenship. The current generation of managers in CEE countries developed their careers in an institutional environment where both they and their principals in centrally planned economies considered output and organizational growth as major features of managerial success (Filatotchev et al. 2000). Alternatively, business students in CEE countries grew up during the post-socialist transition toward a market economy, which has been characterized by economic turbulence and uncertainty (Hoskisson et al. 2000).

In contrast, the relative economic stability over the past few decades in Western European countries suggests that there would be less generational differences in business-related attitudes in these contexts. This is consistent with Inglehart's (1997) finding that there were larger intergenerational values differences in transitional countries which had experienced rapid economic change than in richer and more stable countries. Therefore, we expect that any generation gap in CR perspectives between managers and business students would be more significant in CEE countries than in Western European countries. Hence, we propose:

Hypothesis 3. The generation gap between managers and business students in the importance 
attributed to social CR, economic CR, and environmental CR is more significant in CEE countries than in Western European countries.

\section{Methodology}

\section{Data Collection}

Study participants were 3064 managers and business students in 8 European countries (4 Western European countries - France, Italy, Spain, and Switzerland; and 4 Central and East European countries - Croatia, Czech Republic, Lithuania, and Russia). The Czech Republic and Lithuania are two CEE countries which recently joined the European Union, whereas Croatia is an EU candidate country. Russia was included given its dominant role in the former U.S.S.R. and influence among Eastern Bloc countries.

The period of data collection was 2002-2004. A cross-sectional sampling design was used in a mail survey to collect the manager data (23 percent average response rate, range was 15 percent to 43 percent). The student data was obtained from business students in the classroom. See Table 1 for country sample demographic characteristics (age, gender, and education level).

[Insert Table 1 about here]

\section{Measures}

The survey questionnaire was translated using standard translation-back-translation procedures from English into each of the native languages of the countries in the study. To measure social and economic corporate responsibilities, we used Maignan and Ferrell's (2003) 16-item measure of consumers' perceptions of corporate social responsibilities. This cross-culturally validated instrument consists of 4 subscales measuring the perceived importance of economic, legal, ethical, and discretionary corporate responsibilities (per Carroll, 1979, 1999). Although Maignan and Ferrell (2003) found that these subscales loaded onto 4 separate factors, exploratory factor analysis showed that this was a two-factor measure (after retaining items with factor loadings greater than 0.50). One factor consisted of 4 items including two ethical responsibility items ("give priority to ethical principles over economic benefits", "be committed to well-defined ethics principles") and two discretionary responsibility items ("contribute actively to the welfare of our community", "help solve social problems"). The second factor consisted of 2 economic 
responsibility items ("worry first and foremost about maximizing profits", "always be concerned first about economic performance").

Based on a review of previous measures of proactive corporate environmental management (Branzei/Vertinsky 2002, Egri/Hornal 2002), we developed a 9-item measure of environmental corporate responsibility. Exploratory factor analysis showed a 3-item environmental CR scale ("prevent environmental degradation caused by the pollution and depletion of natural resources", "adopt formal programs to minimize the harmful impact of organizational activities on the environment", "minimize the environmental impact of all organizational activities"). In the survey, participants were asked to indicate the degree to which they agreed (using a 9-point Likert-type scale, $1=$ strongly disagree to $9=$ strongly agree) that it was the duty of businesses to engage in corporate social, economic, and environmental responsibility activities.

Confirmatory Factor Analyses (CFA) for the individual country samples showed configural invariance for the three $\mathrm{CR}$ scales: range of $\mathrm{RMSEA}=0.04$ to 0.08 , $\mathrm{GFI}=0.93$ to $0.97, \mathrm{CFI}=$ 0.92 to 0.97 (cf. Steenkamp/Baumgartner 1998). Full measurement invariance was not attained therefore within-subject standardized scores for the three CR scales were used to test hypotheses (e.g., Sin/Cheung/Lee 1999). The resulting standardized scores represent the relative importance of each type of corporate responsibility. For the total sample, the scale internal reliabilities (Cronbach alpha) were: 0.64 for social $\mathrm{CR}, 0.68$ for the economic $\mathrm{CR}$, and 0.71 for environmental CR. Although some alphas were below the optimal level, internal consistency seemed adequate for this study. Table 2 presents the sample means, standard deviations, and scale reliabilities for the three CR scales.

[Insert Table 2 about here]

\section{Results}

A MANCOVA was conducted to test the differences in attitudes toward social, economic, and environmental corporate responsibilities. In the MANCOVA, the dependent variables were the three CR scores, the independent variables were country, manager/student, and the country-bymanager/student interaction term, and the covariates were gender and education level. Given a high correlation between participant age and the manager/student variable $(r=0.67, p<0.001)$, age was not included in the analysis.

The MANCOVA results showed significant effects for country, manager/student, country- 
by-manager/student as well as for gender (all at $\mathrm{p}=0.001$ level). Education level was not significant and there were no other significant interaction effects. Table 3 presents the results for the MANCOVA and post hoc group comparisons for hypothesis tests.

[Insert Table 3 about here]

\section{Country Differences in CR Attitudes}

Hypothesis 1 proposed that participants in Western European countries would attribute higher importance to social $\mathrm{CR}\left(\mathrm{H}_{1 \mathrm{a}}\right)$ and environmental $\mathrm{CR}\left(\mathrm{H}_{1 \mathrm{c}}\right)$, but lower importance to economic $\mathrm{CR}\left(\mathrm{H}_{1 \mathrm{~b}}\right)$ than participants in CEE countries. The MANCOVA showed significant country differences for social CR, economic CR, and environmental CR (all at $\mathrm{p}<0.001$ level). Consistent with Hypothesis 1a, participants in Italy and Switzerland attributed higher importance to social CR than participants in CEE countries, and French participants attributed higher importance to social CR than did participants in Lithuania, the Czech Republic, and Russia. Inconsistent with Hypothesis 1a, Spanish participants had similar social CR scores as CEE participants, and French participants had similar social CR scores as Croatian participants.

Consistent with Hypothesis $1 \mathrm{~b}$, participants in CEE countries attributed higher importance to economic CR than did participants in Western Europe countries. Consistent with Hypothesis 1c, Western Europe participants attributed higher importance to environmental CR than participants in Croatia, Lithuania, and Russia. Further, participants in Spain attributed higher importance to environmental CR than did Czech Republic participants. Inconsistent with Hypothesis 1c, Czech Republic participants had similar environmental CR scores as those in France, Italy, Switzerland. In sum, Hypothesis 1a was partially supported, Hypothesis 1b was fully supported, and Hypothesis 1c was moderately supported.

\section{Generational Differences in CR Attitudes}

Hypothesis 2 proposed that regardless of country, managers attribute higher importance to social $\mathrm{CR}\left(\mathrm{H}_{2 \mathrm{a}}\right)$ and economic $\mathrm{CR}\left(\mathrm{H}_{2 \mathrm{~b}}\right)$ but lower importance to environmental $\mathrm{CR}\left(\mathrm{H}_{2 \mathrm{c}}\right)$ than business students. Consistent with Hypothesis 2, managers attributed higher importance to social CR ( $\mathrm{p}<$ $0.001)$ and lower importance to environmental $\mathrm{CR}(\mathrm{p}<0.01)\left(\mathrm{H}_{2 \mathrm{a}}\right.$ and $\mathrm{H}_{2 \mathrm{c}}$ supported). There was no significant difference between managers and students in economic $\mathrm{CR}$ scores $\left(\mathrm{H}_{2 \mathrm{~b}}\right.$ not supported). 


\section{Country-by-Generation Differences in CR Attitudes}

Hypothesis 3 proposed that there would be more significant generational differences (managers vs. business students) in CEE countries than in Western European countries. Our test of Hypothesis 3 was the country-by-manager/student interaction which was found to be significant for social CR $(\mathrm{p}<0.001)$ and environmental CR $(\mathrm{p}<0.01)$, but not for economic CR. Withincountry t-test results showed that managers had higher social CR and lower environmental CR scores than business students in the Czech Republic and Italy. However, there were no significant managers vs. student differences for Croatia, France, Italy, Lithuania, Spain, and Russia. In sum, Hypothesis 3 was not supported.

\section{Discussion and Conclusion}

This study found substantive differences in European managers' and business students' perspectives on the relative importance of social, economic, and environmental corporate responsibilities. Consistent with cultural modernization theory predictions that postmaterialist values concerned with environmental protection are more prevalent in advanced industrialized societies (Inglehart/Welzel 2005), managers and business students in Western Europe attributed higher importance to environmental $\mathrm{CR}$ than to social $\mathrm{CR}$, followed by economic CR. Also consistent with cultural modernization theory (Inglehart/Welzel 2005), managers and business students in Lithuania and Russia viewed economic CR as being more important than social CR. These findings support previous research that has found Lithuanian employees and firms accord higher priority to profits over social responsibility in business (Vasiljeviene/Vasiljev 2005), and that the low perceptions of the social role of business in society in Russia (Litovchenko/Korsakov 2003). Contrary to expectations, Lithuanian and Russian respondents viewed environmental CR as being as important as economic CR. This finding suggests that environmental responsibility may be viewed as compatible with achieving economic objectives in transitional economies that have significant environmental problems. However, our findings for Croatia and the Czech Republic suggest caution about generalizations about CR priorities in transitional economies. In

these two countries, managers and students had similar CR rankings as their counterparts in Western European countries, albeit Czech students attributed similarly lower importance to social $\mathrm{CR}$ and economic CR. Hence, this study found some support for the view that economic wealth 
may not be the primary determinant of environmental concern (e.g., Dunlap/Gallup/Gallup 1998).

In respect to country differences in $\mathrm{CR}$ priorities, the primary difference was between Western European and CEE countries. As predicted by Inglehart and Welzel's (2005) postmaterialist hypothesis, managers and business students in Western European countries accord relatively higher importance to social $\mathrm{CR}$ and lower importance to economic CR than do their counterparts in CEE countries. These findings are also consistent with previous country-level business ethics studies that have found a positive relationship between economic wealth and ethical business practices (e.g., Getz/Volkema 2001, Singhapakdi et al. 2001, Vynoslavska et al. 2005) and pro-environmental attitudes (e.g., Diekmann/Franzen 1999, Kemmelmeier et al. 2002). Further, we found support for slack resources theory predictions that firms without slack financial resources, such as in most CEE transitional countries, may have fewer resources to invest in social CR and environmental CR (Orlitzky/Schmidt/Rynes 2003, Waddock/Graves 1997).

However, even though CEE transitional economies had a common starting point, these countries have pursued different transition paths and have achieved different degrees of progress (Hoskisson et al. 2000, Svejnar 2002). Several transitional economies have not performed as well as expected and economic performance varies widely across CEE countries. Central European countries such as the Czech Republic have generally performed better than the Baltic states, including Lithuania, which in turn have performed better than Russia (Svejnar 2002). Furthermore, some CEE countries such as the Czech Republic and Lithuania have accelerated their transition to meet Western social, economic, and environmental standards to join the European Union in 2004. This external pressure may have triggered the adoption of attitudes in line with EU expectations regarding corporate responsibilities (Aguilera/Cuervo-Cazurra 2004, De Schutter 2008). Consistent with this argument, our study found respondents in the Czech Republic to have attitudes close to those in the other EU member countries. The rapidity of this forced transition could also explain why the manager/student differences in the importance attributed to social and environmental corporate responsibilities is the largest for Czech Republic participants. However, joining the EU appears not to have had a similar effect in Lithuania. This could be attributed to Lithuania still having a relatively low level of economic performance and a very strong recurrence of communist ideology in the mass consciousness (Svejnar 2002, Vasiljeviene/Vasiljev 2005). Indeed, Vasiljeviene and Vasiljev (2005) found that Lithuanian companies still regard all social problems as entirely a concern and responsibility only for the 
Ministry of Social Security and Labor.

Another contribution of this study was our examination of generational differences in CR attitudes. Contrary to previous U.S.-based research (e.g., Ibrahim/Angelidis 1993, Ibrahim et al. 2006), we did not find significant differences between European managers and business students in the importance accorded to economic responsibilities. Neither did we find generational differences in attitudes towards social CR and environmental CR for six of the eight European countries in this study (i.e., Croatia, France, Lithuania, Russia, Spain, and Switzerland). However, for the Czech Republic and Italy, our findings support previous research in that business students attributed higher importance to environmental CR than their managerial counterparts (e.g., Diamantopoulos et al. 2003). That managers in the Czech Republic and Italy attributed higher importance to social CR than business students is also consistent with moral development theory (Kohlberg 1981, Sparks/Hunt 1998, Wood et al. 1988) rather than with more recent U.S.-based research suggesting that business students have more ethical dispositions than managers (e.g., Ibrahim et al. 2006).

\section{Limitations and Future Research}

Although this study of attitudes towards social, economic, and environmental corporate responsibilities included samples from eight different European countries, additional countries may be needed to confirm our findings regarding country and demographic influences on these attitudes. Transitional economies are by definition rapidly evolving, therefore it is particularly important to replicate this study to monitor changes in managers' and business students' attitudes toward CR. Future replications are needed given the EU impetus to achieve a European-wide standard of CR policies and practices with particular attention on its new members from Central and East Europe quickly reaching the level of their Western counterparts.

Whereas moral development theory (Kohlberg 1981) suggests that individuals become more ethical with age and experience, formal education is also be an influential factor in attitude formation. For instance, U.S.-based research has found that the study of business and economics leads students to become more self-interested and less concerned with social and environmental issues (e.g., Ferraro/Pfeffer/Sutton 2005, Frank/Gilovich/Regan 1993, 1996). Further, Ferraro et al. (2005) proposed that the adoption of self-interested economics assumptions and norms may be more likely in individualistic Western societies that have independent construals of self than in 
non-Western societies that have more interdependent construals of self. Although our samples of business students were enrolled at the undergraduate level, one limitation of this study is that we did not collect specific information regarding the number and type of business and economics courses that they had completed. As such, we could not directly examine the extent to which formal business and economics education had influenced students' attitudes towards corporate responsibilities. Hence, future cross-national research is needed to directly investigate the effect of business and economics education on CR attitudes and norms across a variety of cultural and institutional contexts.

Another limitation of this study is that we were concerned with the relative importance of different types of corporate responsibilities. While the strong linkage between attitudes and behaviors has been well established (Ajzen, 1996), further multi-country research of managers and business students is needed regarding the linkage between attitudes toward corporate responsibilities and managerial actions.

\section{Managerial Implications}

While the study of cross-national and cross-generational differences in attitudes towards corporate responsibilities is in the embryonic stage, our findings have important implications for international managers and multinational corporations that operate across European national borders in that they clearly indicate certain types of corporate responsibilities are viewed more positively in certain socio-economic contexts. These managerial implications can be discussed from two perspectives: (1) external institutional influences; and (2) internal social constructions.

External institutional influences. As CR attitudes remain different between Western European and CEE countries, multinational corporations (MNCs) may be faced with an ethical dilemma as to whether to maintain and implement similar CR practices across countries or to adapt their CR practices to local conditions (Donaldson 1996, Hoskisson et al. 2000, Peng 2003). As such, MNCs may be under pressure to meet the potentially conflicting goals of global integration and local responsiveness with respect to CR issues (Husted/Allen 2006).

The proliferation of transnational initiatives, such as the UN Global Compact and the Global Reporting Initiative, has increased macro-level institutional pressures for global integration and consistency in corporate responsibility (e.g., Gilbert/Rasche 2008, Waddock 2008). The global standardization of ethical corporate conduct promises efficiency and reputational benefits for 
MNCs, as well as the potential for exerting influence to reduce cross-national disparities in regulatory and normative institutional environments. Indeed, there is evidence that MNCs which espouse and practice a high level of social responsibility and ethical conduct can and do act as positive social and institutional change agents (Bies/Bartunek/Fort/Zald 2007, Kwok/Tadesse 2006).

Even so, current transnational initiatives are largely voluntary, communication and implementation processes with various stakeholders are generally undefined, and they may be very costly for small and medium enterprises (Gilbert/Rasche 2008). Hence, MNCs may adopt a relativistic approach with $\mathrm{CR}$ programs that accept the institutional and attitudinal differences in various host environments, and focuses on the most important CR issues in the country in which they are operating. In this regard, Scherer and Smid (2000) argue that there are limited reins on the power of economic systems to prevent MNCs with poor CR performance from opportunistically transferring activities to countries that have lower social and environmental standards and regulatory systems. Labor intensive activities (e.g., using children with small fingers to create hand tied rugs) may be transferred to countries where social responsibilities are perceived as less important, while polluting activities (e.g., powering a factory on soft coal without scrubbers on the smokestacks) may be transferred to countries where environmental responsibilities are perceived as less important. Indeed, MNCs may actively lobby governments and local institutions to advance a downward spiral towards lower social and environmental expectations and standards (Scherer/Smid 2000).

Internal social constructions. Perspectives on $\mathrm{CR}$ are not only influenced by external institutional factors, they are also social constructions. Basu and Pallazo (2007) propose that CR is socially constructed within organizations and that it reflects the shared perspectives of organizational members which in turn, constitute an organizational identity. As proposed by Brickson (2007), CR is most consistent with organizational identity orientations that engender relational (based on concern and trust) and collectivistic (based on a common collective agenda) stakeholder relationships, rather than individualistic (instrumental and self-interested) stakeholder relationships. One might ask: to what extent are the normative expectations of current and future business leaders supportive of a CR organizational identity? First, we found an emerging normative consensus across Europe that environmental CR is relatively more important than social CR, although to varying degrees. However, the same cannot be said in respect to normative 
expectations regarding the relative importance of social $\mathrm{CR}$, in general and compared to economic CR. Our study suggests that organizations that operate in Western European countries as well as in Croatia and the Czech Republic can expect relatively high internal support for social CR activities, but that organizations operating in Lithuania and Russia may encounter more internal resistance to social $\mathrm{CR}$ activities which are viewed as subsidiary to the pursuit of economic profits. And the lack of significant differences in CR attitudes between managers and business students in both Lithuania and Russia suggests that such internal resistance to social CR is likely to continue into the future (cf. Andreev 2008).

One result may be crossvergent organizational identity hybrids that appear to have inconsistent and/or divergent CR motivations and actions, whether at different points of time or in different organizational locations (Brickson 2007). This prospect would be particularly challenging for MNCs seeking a coherent transnational CR identity and strategy for developing internal and external stakeholder relationships (Basu/Pallazo 2007; Brickson 2007). Our findings suggest that organizational change agency for advancing CR (Bies/Bartunek/Fort/Zald 2007) would be more pressing in transitional economies such as Russia and Lithuania. Internal change agency would require strong and active leadership to ensure that proactive CR objectives are not compromised in implementation (Basu/Palazzo 2007). Engendering a CR organizational identity would involve not only ensuring adherence to formal codes of ethical conduct but also ensuring that human resource management practices (recruitment, promotion, training, reward systems, etc.) reinforce these organizational values and practices (Egri/Hornal 2002).

External change agency would require diligence in forming and managing relationships with other organizations-supply chain partners, industry affiliates, and the wider business community. Further, there would be a need for outreach to education institutions to create and teach new business models that have a more balanced relational and collectivistic orientation that emphasizes service to others and collectives rather than an overemphasis on individualistic selfinterest (Birnik/Billsberry 2008; Brickson, 2007).

In sum, this study, as the first to simultaneously investigate CR practices across different societies and different generations within those societies, reveals the value of multi-level research, for both academics and practitioners, in advancing knowledge about the diffusion of perspectives on corporate responsibilities. As this study has implied, the directions for future research are many. However, we believe that one of the most important future research endeavors 
should consist of obtaining a more globally inclusive set of countries for comparison.

\section{References}

Agle, B. R./Mitchell, R. K./Sonnenfeld, J. A., Who Matters to CEOs? An Investigation of Stakeholder Attributes and Salience, Corporate Performance, and CEO Values, Academy of Management Journal, 42, 5, 1999, pp. 507-525.

Aguilera, R. V./Cuervo-Cazurra, A., Codes of Good Governance Worldwide: What is the Trigger? Organization Studies, 25, 3, 2004, pp. 415-443.

Aguilera, R. V./Rupp, D. E./Williams, C. A./Ganapathi, J., Putting the S Back in Corporate Social Responsibility: A Multilevel Theory of Social Change in Organizations, Academy of Management Review, 32, 3, 2007, pp. 836-863.

Ajzen, I., The Social Psychology of Decision Making, in Higgins, E. T./ Kruglanski, A. W. (eds.), Social Psychology: Handbook of Basic Principles, New York: Guilford 1996, pp. 297-325.

Albareda, L./Lozano, J. M./Ysa, T., Public Policies on Corporate Social Responsibility: The Role of Governments in Europe, Journal of Business Ethics, 74, 4, 2007, pp. 391-407.

Andreev, A. L., Russians' Mentality and Problems of Social Inequality, Sociological Research, 47, 5, 2008, pp. 52-62.

Antal, A.B./Sobczak, A. Corporate Social Responsibility in France: A Mix of National Traditions and International Influences, Business \& Society, 46, 1, 2007, pp. 9-32.

Aupperle, K. E./Carroll, A. B./Hatfield, J. D., An Empirical Examination of the Relationship Between Corporate Social Responsibility and Profitability, Academic of Management Journal, 28, 2, 1985, pp. 446-463.

Basu, K./Palazzo, G., Corporate Social Responsibility: A Process Model of Sensemaking, Academy of Management Review, 33, 1, 2008, pp. 122-136.

Bies, R. J./Bartunek, J. M./Fort, T. L./Zald, M. N., Corporations as Social Change Agents: Individual, Interpersonal, Institutional, and Environmental Dynamics, Academy of Management Review, 32, 3, pp. 788-793.

Birnik, A./Billsberry, J., Reorienting the Business School Agenda: The Case for Relevance, Rigor, and Righteousness, Journal of Business Ethics, 82, 4, 2008, pp. 985-999.

Branzei, O./Vertinsky, I., Eco-Sustainability Orientation in China and Japan: Differences 
Between Proactive and Reactive Firms, in Sharma S./Starik M. (eds.), Research in Corporate Sustainability: The Evolving Theory and Practice of Organizations in the Natural Environment, Northhampton (MA): Edward Elgar 2002, pp. 85-122.

Brickson, S. L., Organizational Identity Orientation: The Genesis of the Role of the Firm and Distinct Forms of Social Value, Academy of Management Review, 32, 3, 2007, pp. 864-888.

Campbell, J. L. Why Would Corporations Behave in Socially Responsible Ways? An Institutional Theory of Corporate Social Responsibility, Academy of Management Review, 32, 3, 2007, 946-967.

Carroll, A. B., A Three-Dimensional Conceptual Model of Corporate Performance, Academy of Management Review, 4, 4, 1979, pp. 497-505.

Carroll, A. B., Corporate Social Responsibility: Evolution of a Definitional Construct, Business \& Society, 38, 3, 1999, pp. 268-295.

De Schutter, O., Corporate Social Responsibility European Style, European Law Journal, 14, 2, 2008, pp. 203-236.

Diamantopoulos, A./Schlegelmilch, B. B./Sinkovics, R. R./Bohlen, G. M., Can SocioDemographics Still Play a Role in Profiling Green Consumers? A Review of the Evidence and an Empirical Investigation, Journal of Business Research, 56, 6, 2003, pp. 465-480.

Diekmann, A./Franzen, A., The Wealth of Nations and Environmental Concern, Environment and Behavior, 31, 4, 1999, pp. 540-549.

Donaldson, T., Values in Tension: Ethics Away from Home, Harvard Business Review, September-October, 1996, pp. 4-11.

Dunlap, R. E./Gallup Jr., G. H./Gallup, A. M., Of Global Concern: Results of the Health of the Planet Survey, Environment, 35, 9, 1993, pp. 6-14, 33-40.

Egri, C. P./Hornal, R. C., Strategic Environmental Human Resource Management and Perceived Organizational Performance: An Exploratory Study of the Canadian Manufacturing Sector, in Sharma, S./Starik M. (eds.), Research in Corporate Sustainability: The Evolving Theory and Practice of Organizations in the Natural Environment, Northhampton: Edward Elgar 2002, pp. 205-236.

Egri, C. P./Ralston, D. A., Corporate Responsibility: A Review of International Management Research from 1998 to 2007, Journal of International Management, 14, 4, 2008, pp319-339. Ericson, R. E., The Classical Soviet-Type Economy: Nature of the System and Implications for 
Reform' Journal of Economic Perspectives, 5, 4, 1991, pp. 11-27.

European Commission, Corporate Social Responsibility: A Business Contribution to Sustainable

Development, 2002, http://ec.europa.eu (accessed 18 January 2008).

European Commission, Promoting a European Framework for Corporate Social Responsibility:

Green Paper 2001, http://ec.europa.eu (accessed 18 January 2008).

Ferraro, F./Pfeffer, J./Sutton, R. I., Economics Language and Assumptions: How Theories Can

Become Self-fulfilling, Academy of Management Review, 30, 1, 2005, pp. 8-24.

Filatotchev, I./Buck, T./Zhukov, V., Downsizing in Privatized Firms in Russia, Ukraine, and

Belarus, Academy of Management Journal, 43, 3, 2000, pp. 286-304.

Frank, R. H./Gilovich, T. D., Do Economists Make Bad Citizens? Journal of Economic Perspectives, 10, 1, 1996, pp. 187-192.

Frank, R. H./Gilovich, T./Regan, D. T., Does Studying Economics Inhibit Cooperation? Journal of Economic Perspectives, 7, 2, 1993, pp. 159-171.

Freeman, R. E., Strategic Management: A Stakeholder Approach, Boston: Pitman 1984.

Georgas, J./van de Vijver, F. J. R./Berry, J. W., The Ecocultural Framework, Ecosocial Indices, and Psychological Variables in Cross-cultural Research, Journal of Cross-Cultural Psychology, 35, 1, 2004, pp. 74-96.

Getz, K. A./Volkema, R. J., Culture, Perceived Corruption, and Economics: A Model of Predictors and Outcomes, Business and Society, 40, 1, 2001, pp. 7-30.

Gilbert, D./Rasche, A., Opportunities and Problems of Standardized Ethics Initiatives: A Stakeholder Theory Perspective. Journal of Business Ethics, 82, 3, 2008, pp. 755-773.

Glaeser, E. L./La Porta, R./Lopez-de-Silanes, F./Shleifer, A., Do Institutions Cause Growth? Journal of Economic Growth, 9, 3, 2004, pp. 271-303.

Habisch, A./Jonker, J./Wegner, M./Schmidpeter R. (eds.), Corporate Social Responsibility across Europe, Berlin: Springer 2005.

Hood, J. N., The Relationship of Leadership Style and CEO Values to Ethical Practices in Organizations, Journal of Business Ethics, 43, 4, 2003, pp. 263-273.

Hoskisson, R. E./Eden, L./Lau, C. M./Wright, M., Strategy in Emerging Economies, Academy of Management Journal, 43, 3, 2000, pp. 249-267.

Husted, B. W./Allen, D. B., Corporate Social Responsibility in the Multinational Enterprise: Strategic and Institutional Approaches, Journal of International Business Studies, 37, 6, 
2006, pp. 838-849.

Ibrahim, N. A./Angelidis, J. A., Corporate Social Responsibility: A Comparative Analysis of Perceptions of Top Executives and Business Students, The Mid-Atlantic Journal of Business, 29, 3, 1993, pp. 303-313.

Ibrahim, N./Angelidis, J./Howard, D., Corporate Social Responsibility: A Comparative Analysis of Perceptions of Practicing Accountants and Accounting Students, Journal of Business Ethics, 66, 2/3, 2006, pp. 157-167.

Inglehart, R. 1997. Modernization and Postmodernization: Cultural, Economic, and Political Change in 43 Societies, Princeton: Princeton University Press.

Inglehart, R./Welzel, C. Modernization, Cultural Change, and Democracy: The Human Development Sequence, New York: Cambridge University Press, 2005.

Kaufmann, D./Kraay, A., Growth without Governance, Economia, 3, 1, 2002, pp. 169-229.

Kemmelmeier, M./Krol, G./Kim, Y. H., Values, Economic, and Proenvironmental Attitudes in 22 Societies, Cross-Cultural Research, 26, 3, 2002, pp. 256-285.

Klages, H. Modernization and Value Change, in Friedlmeier, W./Chakkarath, P./Schwarz, B. (eds.), Culture and Human Development: The Importance of Cross-Cultural Research for the Social Sciences, Hove: Psychology Press 2005, pp. 273-287.

Kohlberg, L., The Meaning and Measurement of Moral Development, Worcester (MA): Clark University Press 1981.

Kornai, J., The Socialist System: The Political Economy of Communism, Princeton (NJ): Princeton University Press 1992.

Kwok, C. C. Y./Tadesse, S., The MNC as an Agent of Change for Host-Country Institutions: FDI and Corruption, Journal of International Business Studies, 37, 6, 2006, pp. 767-785.

Lenssen, G./Vorobey, V., The Role of Business in Society in Europe, in Habisch, A. et al. (eds.), Corporate Social Responsibility Across Europe, Berlin: Springer 2005, pp. 357-375.

Litovchenko, S./Korsakov, M. (eds.), Corporate Social Responsibility: Public Expectations, Moscow 2003.

Maignan, I./Ferrell, O. C., Nature of Corporate Responsibilities: Perspectives from American, French, and German Consumers, Journal of Business Research, 56, 1, 2003, pp. 55-67.

Mitchell, R. K./Agle, B. R./Wood, D. J., Toward a Theory of Stakeholder Identification and Salience: Defining the Principle of Who and What Really Counts, Academy of Management 
Review, 22, 4, 1997, pp. 853-886.

Mitchell, W. J./Lewis, P. V./Reinsch, Jr., N. L., Bank Ethics: An Exploratory Study of Ethical Behaviors and Perceptions in Small, Local Banks, Journal of Business Ethics, 11, 3, 1992, pp. 197-205.

North, D. C., Institutions, Institutional Change and Economic Performance, Cambridge: Harvard University Press 1990.

Orlitzky, M./Schmidt, F. L./Rynes, S. L., Corporate Social and Financial Performance: A MetaAnalysis, Organization Studies, 24, 3, 2003, pp. 403-441.

Peng, M. W., Institutional Transitions and Strategic Choices, Academy of Management Review, 28, 2, 2003, pp. 275-296.

Pinkston, T. S./Carroll, A. B., Corporate Citizenship Perspectives and Foreign Direct Investments in the U.S., Journal of Business Ethics, 13, 3, 1994, pp. 157-169.

Ralston, D. A., The Crossvergence Perspective: Reflections and Projections, Journal of International Business Studies, 39, 1, 2008, pp. 27-40.

Scherer, A. G./Smid, M. "The Downward Spiral and the US Model Business Principles: Why MNEs Should Take Responsibility for the Improvement of World-Wide Social and Environmental Conditions, Management International Review, 40, 4, 2000, pp. 351-371.

Schlegelmilch, B. B./Robertson, D. C., The Influence of Country and Industry on Ethical Perceptions of Senior Executives in the U.S. and Europe, Journal of International Business Studies, 26, 4, 1995, pp. 859-881.

Schwartz, S. H. Universals in the Content and Structure of Values: Theoretical Advances and Empirical Tests in 20 Countries, in Zanna, M. P. (ed.), Advances in Experimental Social Psychology, San Diego: Academic Press 1992, pp. 1-65.

Scott, W. R., Institutions and Organizations, Thousand Oaks: Sage, 1995.

Sharfman, M. P./Pinkston, T. S./Sigerstad, T. D., The Effects of Managerial Values of Social Issues Evaluation: An Empirical Examination, Business and Society, 39, 2, 2000, pp. 144-182. Shrivastava, P., Greening Business: Profiting the Corporation and the Environment, Cincinnati: Thompson Executive Press 1996.

Scherer, A. G./Smid, M. "The Downward Spiral and the US Model Business Principles: Why MNEs Should Take Responsibility for the Improvement of World-Wide Social and Environmental Conditions, Management International Review, 40, 4, 2000, pp. 351-371. 
Sin, L. Y. M./Cheung, G. W. E./Lee, R., Methodology in Cross-Cultural Consumer Research: A Review and Critical Assessment, Journal of International Consumer Marketing, 11, 4, 1999, pp. 75-96.

Singhapakdi, A./Karande, K./Rao, C. P./Vitell, S. J., How Important are Ethics and Social Responsibility? A Multinational Study of Marketing Professionals, European Journal of Marketing, 35, 1/2, 2001, pp. 133-145.

Smith, D./Skalnik, J./Skalnik, P., Ethical Behavior of Marketing Managers and MBA Students, Teaching Business Ethics, 3, 4, 1999, pp. 321-335.

Sparks, J. R./Hunt, S. D., Marketing Researcher Ethical Sensitivity: Conceptualization, Measurement, and Exploratory Investigation, Journal of Marketing, 62, 1, 1998, pp. 92-109.

Steenkamp, J-B. E. M./Baumgartner, H., Assessing Measurement Invariance in Cross-National Consumer Research, Journal of Consumer Research, 25, 1, 1998, pp. 78-90.

Svejnar, J., Transition Economies: Performance and Challenges, Journal of Economic Perspectives, 16, 1, 2002, pp. 3-28.

Vasijeviene, N./Vasiljev, A., Lithuania. The Roadmap: From Confrontation to Consensus, in Habisch, A. et al. (eds.), Corporate Social Responsibility Across Europe, Berlin: Springer 2005, pp. 183-193.

Vaughan-Whitehead, D. C., EU Enlargement versus Social Europe? The Uncertain Future of the European Model, Cheltenham: Edward Elgar Publishing 2003.

Vynoslavska, O./McKinney, J. A./Moore, C. W./Longenecker, J. G., Transition Ethics: A Comparison of Ukrainian and United States Business Professionals, Journal of Business Ethics, 61, 3, 2005, pp. 283-299.

Waddock, S. A./Graves, S. B., The Corporate Social Performance-Financial Performance Link' Strategic Management Journal, 18, 4, 1997, pp. 303-319.

Waddock, S., Building a New Institutional Infrastructure for Corporate Responsibility, Academy of Management Perspectives, 22, 3, 2008, pp. 87-108.

Weeks, W. A./Moore, C. W./McKinney, J. A./Longenecker, J. G., The Effects of Gender and Career Stage on Ethical Judgment, Journal of Business Ethics, 20, 4, 1999, pp. 301-313.

Wood, J. A./Longenecker, J. G./McKinney, J. A./Moore, C. W., Ethical Attitudes of Students and Business Professionals: A Study of Moral Reasoning, Journal of Business Ethics, 7, 4, 1988, pp. 249-257. 
Table 1. Demographic Characteristics of Country Samples

\begin{tabular}{|c|c|c|c|c|c|c|c|}
\hline & & & & & Gender & & tion $^{\mathrm{a}}$ \\
\hline & & $\mathbf{N}$ & Mean & (SD) & $\%$ male & Mean & (SD) \\
\hline Croatia & Manager & 282 & 38.6 & (9.4) & 45.4 & 3.8 & $(0.6)$ \\
\hline & Student & 74 & 20.0 & (1.6) & 74.3 & 3.9 & $(0.3)$ \\
\hline Czech Rep. & Manager & 311 & 38.9 & (10.8) & 44.2 & 3.8 & $(1.0)$ \\
\hline & Student & 103 & 22.1 & (1.8) & 35.0 & 3.4 & $(0.5)$ \\
\hline France & Manager & 207 & 37.3 & (11.1) & 59.7 & 4.9 & $(0.1)$ \\
\hline & Student & 91 & 23.3 & $(0.9)$ & 61.8 & 4.9 & $(0.7)$ \\
\hline Italy & Manager & 297 & 43.2 & (10.6) & 77.3 & 4.6 & $(0.9)$ \\
\hline & Student & 100 & 22.1 & (3.5) & 55.0 & 3.0 & $(0.0)$ \\
\hline Lithuania & Manager & 315 & 43.7 & (11.4) & 55.7 & 4.2 & (1.0) \\
\hline & Student & 121 & 20.3 & (1.4) & 21.1 & 3.0 & $(0.0)$ \\
\hline Russia & Manager & 110 & 31.7 & (4.6) & 70.0 & 5.1 & $(0.2)$ \\
\hline & Student & 150 & 19.5 & (1.2) & 33.3 & 4.0 & $(0.0)$ \\
\hline Spain & Manager & 106 & 39.2 & (10.5) & 81.0 & 3.2 & (1.1) \\
\hline & Student & 118 & 23.3 & $(3.8)$ & 45.7 & 3.0 & $(0.0)$ \\
\hline Switzerland & Manager & 368 & 40.9 & (13.6) & 76.2 & 4.1 & $(0.8)$ \\
\hline & Student & 311 & 23.3 & $(2.5)$ & 61.7 & 3.5 & $(0.5)$ \\
\hline Total & Manager & 1996 & 40.1 & (11.4) & 62.0 & 4.2 & (1.0) \\
\hline & Student & 1068 & 22.0 & $(2.8)$ & 49.0 & 3.5 & $(0.6)$ \\
\hline
\end{tabular}

${ }^{\mathrm{a}}$ Education level coded as follows: $1=4$ or fewer years completed, $2=5$ to 8 years, $3=9$ to 12 years; $4=$ Bachelor degree; 5 = Masters degree, $6=$ Doctorate. 
Table 2. Attitudes Towards Social, Economic, and Environmental Corporate Responsibilities:

Standardized means, standard deviations, and scale reliabilities (Cronbach alpha)

\begin{tabular}{|c|c|c|c|c|c|c|c|c|c|c|c|}
\hline & & \multirow[b]{2}{*}{$\mathbf{N}$} & \multicolumn{3}{|c|}{ Social CR } & \multicolumn{3}{|c|}{ Economic CR } & \multicolumn{3}{|c|}{ Environmental CR } \\
\hline & & & Mean & (SD) & $\alpha$ & Mean & (SD) & $\alpha$ & Mean & (SD) & $\alpha$ \\
\hline \multirow[t]{3}{*}{ Croatia } & Total & 356 & -0.07 & $(0.45)$ & 0.63 & -0.32 & $(0.81)$ & 0.48 & 0.31 & $(0.53)$ & 0.70 \\
\hline & Manager & 282 & -0.08 & $(0.45)$ & & -0.31 & $(0.82)$ & & 0.31 & $(0.52)$ & \\
\hline & Student & 74 & -0.05 & $(0.44)$ & & -0.34 & $(0.74)$ & & 0.30 & $(0.56)$ & \\
\hline \multirow[t]{3}{*}{ Czech Rep. } & Total & 414 & -0.15 & $(0.42)$ & 0.62 & -0.38 & $(0.88)$ & 0.69 & 0.45 & $(0.51)$ & 0.60 \\
\hline & Manager & 311 & -0.11 & $(0.40)$ & & -0.36 & $(0.89)$ & & 0.39 & $(0.52)$ & \\
\hline & Student & 103 & -0.28 & $(0.44)$ & & -0.43 & $(0.87)$ & & 0.66 & $(0.43)$ & \\
\hline \multirow[t]{3}{*}{ France } & Total & 298 & -0.05 & $(0.42)$ & 0.74 & -0.66 & $(0.85)$ & 0.67 & 0.51 & $(0.44)$ & 0.72 \\
\hline & Manager & 207 & -0.03 & $(0.42)$ & & -0.67 & $(0.86)$ & & 0.50 & $(0.44)$ & \\
\hline & Student & 91 & -0.09 & $(0.43)$ & & -0.61 & $(0.83)$ & & 0.53 & $(0.44)$ & \\
\hline \multirow[t]{3}{*}{ Italy } & Total & 397 & 0.06 & $(0.42)$ & 0.71 & -0.78 & $(0.84)$ & 0.68 & 0.43 & $(0.48)$ & 0.79 \\
\hline & Manager & 297 & 0.10 & $(0.42)$ & & -0.81 & $(0.85)$ & & 0.40 & $(0.47)$ & \\
\hline & Student & 100 & -0.06 & $(0.41)$ & & -0.67 & $(0.82)$ & & 0.53 & $(0.49)$ & \\
\hline \multirow[t]{3}{*}{ Lithuania } & Total & 436 & -0.12 & $(0.45)$ & 0.64 & 0.07 & $(0.84)$ & 0.65 & 0.11 & $(0.56)$ & 0.69 \\
\hline & Manager & 315 & -0.10 & $(0.45)$ & & 0.05 & $(0.83)$ & & 0.10 & $(0.57)$ & \\
\hline & Student & 121 & -0.18 & $(0.43)$ & & 0.12 & $(0.86)$ & & 0.16 & $(0.52)$ & \\
\hline \multirow[t]{3}{*}{ Russia } & Total & 260 & -0.15 & $(0.36)$ & 0.50 & 0.14 & $(0.67)$ & 0.57 & 0.10 & $(0.53)$ & 0.80 \\
\hline & Manager & 110 & -0.14 & $(0.35)$ & & 0.07 & $(0.64)$ & & 0.14 & $(0.51)$ & \\
\hline & Student & 150 & -0.15 & $(0.37)$ & & 0.19 & $(0.70)$ & & 0.08 & $(0.54)$ & \\
\hline \multirow[t]{3}{*}{ Spain } & Total & 224 & -0.08 & $(0.42)$ & 0.69 & -0.64 & $(0.79)$ & 0.41 & 0.53 & $(0.46)$ & 0.80 \\
\hline & Manager & 106 & -0.09 & $(0.44)$ & & -0.53 & $(0.84)$ & & 0.47 & $(0.51)$ & \\
\hline & Student & 118 & -0.07 & $(0.41)$ & & -0.74 & $(0.73)$ & & 0.59 & $(0.41)$ & \\
\hline \multirow[t]{3}{*}{ Switzerland } & Total & 679 & 0.05 & $(0.43)$ & 0.67 & -0.78 & $(0.79)$ & 0.66 & 0.45 & $(0.49)$ & 0.70 \\
\hline & Manager & 368 & 0.03 & $(0.43)$ & & -0.76 & $(0.77)$ & & 0.45 & $(0.52)$ & \\
\hline & Student & 311 & 0.06 & $(0.44)$ & & -0.81 & $(0.81)$ & & 0.45 & $(0.46)$ & \\
\hline \multirow[t]{3}{*}{ Total } & Total & 3064 & -0.05 & $(0.42)$ & 0.64 & -0.45 & $(0.88)$ & 0.68 & 0.37 & $(0.53)$ & 0.71 \\
\hline & Manager & 1996 & -0.03 & $(0.43)$ & & -0.44 & $(0.88)$ & & 0.35 & $(0.53)$ & \\
\hline & Student & 1068 & -0.07 & $(0.43)$ & & -0.45 & $(0.89)$ & & 0.40 & $(0.51)$ & \\
\hline
\end{tabular}


Table 3. MANCOVA Results and Summary of Hypothesis Tests

\begin{tabular}{|c|c|c|c|c|}
\hline & Social CR & Economic CR & Environmental CR & Wilks $\Lambda(F)$ \\
\hline Country & $19.99^{* * *}$ & $73.07^{* * *}$ & $35.25^{* * *}$ & $0.83\left(27.98^{\text {**** }}\right)$ \\
\hline Manager/Student & $13.21^{* * *}$ & 1.29 & $7.90^{* *}$ & $0.99\left(5.18^{* * *}\right)$ \\
\hline Country x Manager/Student & $3.37^{* * *}$ & 1.68 & $3.27^{* *}$ & $0.98(2.14 * *)$ \\
\hline Gender & $34.46^{* * *}$ & $46.65^{* * *}$ & 0.70 & $0.98\left(18.78^{* * *}\right)$ \\
\hline Education & 0.28 & 0.17 & 0.01 & $1.00(.38)$ \\
\hline \multicolumn{5}{|l|}{ Hypothesis Tests } \\
\hline $\begin{array}{l}H_{1} . \text { Western Europe countries } \\
>C E E \text { countries }\end{array}$ & $\begin{array}{l}H_{\text {la. }} \text { Partial Support } \\
\text { (Italy, Switzerland) }> \\
\text { (France, Croatia, Spain, } \\
\text { Lithuania, Czech Rep, } \\
\text { Russia); } \\
\text { (France, Croatia) }>\text { (Czech } \\
\text { Rep, Russia); } \\
\text { France > Lithuania }\end{array}$ & $\begin{array}{l}H_{1 b .} \text { Supported } \\
\text { (Russia, Lithuania) }> \\
(\text { Croatia, Czech Rep) }> \\
\text { (Spain, France, } \\
\text { Switzerland, Italy) }\end{array}$ & $\begin{array}{l}H_{1 c} . \text { Moderate Support } \\
\text { (Spain, France, Switzerland, } \\
\text { Czech Rep, Italy) > Croatia > } \\
\text { (Lithuania, Russia); } \\
\text { Spain > (Switzerland, Czech } \\
\text { Rep, Italy); } \\
\text { Italy > France }\end{array}$ & \\
\hline $\mathrm{H}_{2}$. Generational Differences & $\begin{array}{l}H_{2 a} . \text { Supported } \\
\text { Managers }>\text { Students }\end{array}$ & $\begin{array}{l}H_{2 b} . \text { Not Supported } \\
\text { Managers }=\text { Students }\end{array}$ & $\begin{array}{l}\mathrm{H}_{2 c} . \text { Supported } \\
\text { Students }>\text { Managers }\end{array}$ & \\
\hline $\begin{array}{l}H_{3} . \text { Within-country } \\
\text { generational differences: CEE } \\
\text { countries > Western Europe } \\
\text { countries }\end{array}$ & $\begin{array}{l}H_{3 .} \text { Not Supported } \\
\text { Managers > Students: } \\
\text { Czech Rep, Italy. } \\
\text { Managers = Students: } \\
\text { Croatia, France, Italy, } \\
\text { Lithuania, Spain, Russia }\end{array}$ & $H_{3}$. Not Supported. & $\begin{array}{l}H_{3} . \text { Not Supported } \\
\text { Students > Managers: Czech } \\
\text { Rep, Italy. } \\
\text { Managers = Students: Croatia, } \\
\text { France, Italy, Lithuania, Spain, } \\
\text { Russia }\end{array}$ & \\
\hline
\end{tabular}

$\mathrm{p}<<0.05,{ }^{* *} \mathrm{p}<0.01,{ }^{* * * *} \mathrm{p}<0.001$ 
Figure 1. Influences of National Contexts and Generation Cohort on Attitudes Towards Corporate Responsibilities

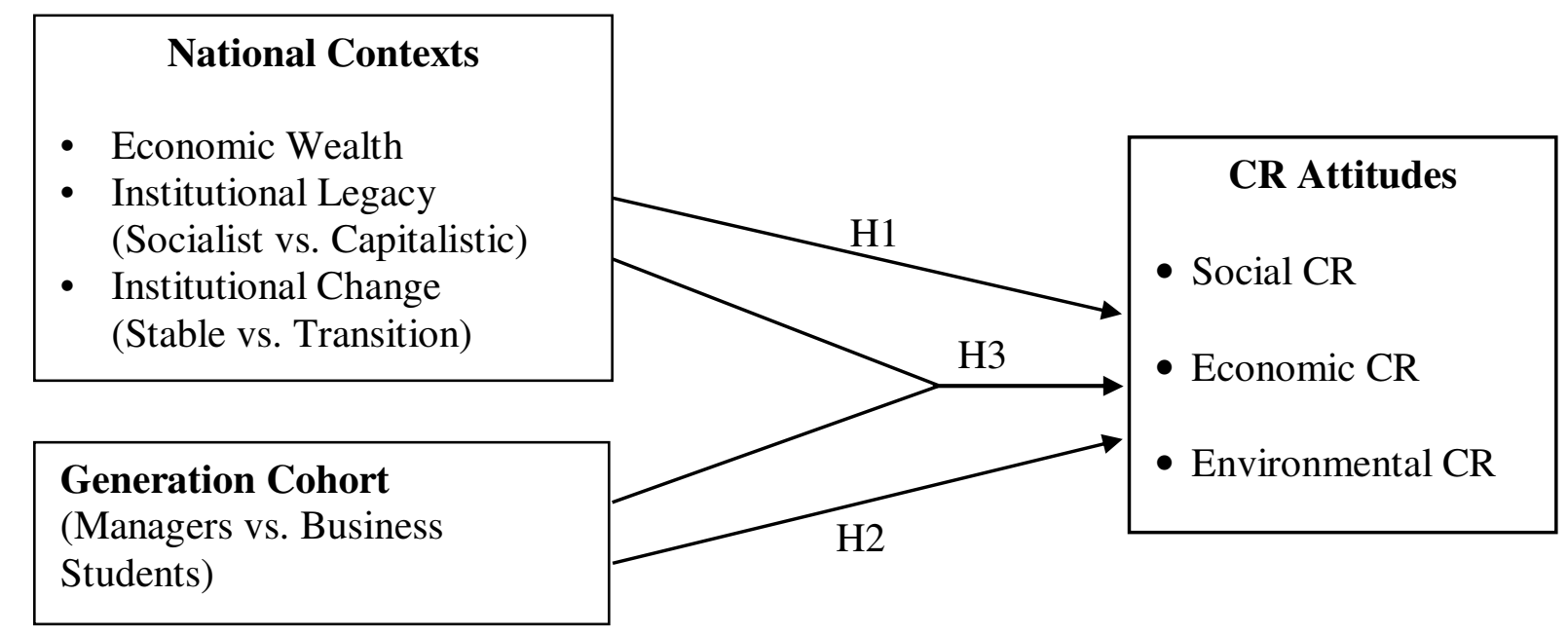

